\title{
Manajemen Komplikasi dan Keluhan pada Pasien yang Menjalani Hemodialisis
}

\author{
Devia Putri Lenggogeni, Hema Malini, dan Boby Febri Krisdianto \\ Fakultas Keperawatan, Universitas Andalas, Kampus Limau Manis, Padang, 25163. Indonesia \\ E-mail: deviaputri@nrs.unand.ac.id
}

Keywords: complication education, hemodialysis, problem management

Kata Kunci: edukasi, hemodialisis, keluhan, manajemen komplikasi

\begin{abstract}
Hemodialysis is one of the renal replacement therapies used by many patients with terminal renal failure. Hemodialysis is an effective renal replacement therapy and is the most commonly used in managing terminal renal failure. However, hemodialysis is a complicated and uncomfortable therapy with several complications. Hemodialysis complications need to be prevented and controlled so that the patient's life remains optimal, and the worse condition does not occur. This program provides knowledge and information to patients undergoing hemodialysis. It used to handle complications and problems caused by terminal renal failure and hemodialysis. This program is an education program to 32 patients undergoing hemodialysis at the hemodialysis unit RSUP. Dr. M. Djamil Padang. The program was carried out by using videos and giving booklet to patients. It showed an increase in patient's knowledge to manage complications and problems caused by hemodialysis. It provides information related to the management of complications and problems in patients undergoing hemodialysis, which can be done by the patient. It is aimed at patients to improve skills in managing complications and problems caused by hemodialysis.
\end{abstract}

\footnotetext{
ABSTRAK

Hemodialisis merupakan salah satu terapi pengganti fungsi ginjal yang banyak digunakan oleh pasien dengan gagal ginjal terminal. Hemodialisis menjadi terapi pengganti ginjal yang efektif dan paling banyak digunakan dalam penatalaksanaan gagal ginjal terminal. Namun, hemodialisis menjadi terapi yang rumit dan tidak nyaman yang disertai dengan beberapa komplikasi. Komplikasi hemodialisis perlu dicegah dan dikendalikan agar hidup pasien tetap optimal dan kondisi yang lebih buruk tidak terjadi. Kegiatan ini berupaya untuk memberikan pengetahuan dan informasi kepada pasien yang menjalani hemodialisis terkait penanganan komplikasi dan keluhan yang diakibatkan oleh penyakit gagal ginjal terminal dan hemodialisis. Kegiatan ini merupakan edukasi yang diberikan kepada 32 orang pasien yang menjalani hemodialisis di unit hemodialisis RSUP. Dr. M. Djamil Padang. Kegiatan dilakukan dengan penggunaan video dan pemberian modul edukasi kepada pasien. Kegiatan memberikan informasi terkait manajemen komplikasi dan keluhan pada pasien yang menjalani hemodialisis yang dapat dilakukan secara mandiri oleh pasien. Hasil kegiatan menunjukkan adanya peningkatan pengetahuan pasien untuk mengatasi komplikasi dan keluhan yang diakibatkan oleh tindakan hemodialisis. Melalui peningkatan pengetahuan ini diharapkan pasien mempunyai keterampilan untuk mengelola komplikasi dan keluhan yang dirasakan oleh pasien.
} 


\section{PENDAHULUAN}

Gagal ginjal terminal (GGT) merupakan kelainan struktur atau penurunan fungsi ginjal dengan perkiraan laju filtrasi glomerulus (LFG) $<15 \mathrm{ml} /$ menit/1,73 $\mathrm{m}^{2}$ yang telah terjadi lebih dari 3 bulan yang bersifat progresif dan tidak dapat dikembalikan lagi fungsinya sehingga tubuh tidak dapat mempertahankan metabolism dan keseimbangan cairan dan elektrolit serta menyebabkan terjadinya uremia (Sukandar, 2013). Pada keadaan ini maka diperlukan terapi pengganti ginjal berupa dialysis atau transplantasi ginjal (Suwitra, 2014). Terapi pengganti ginjal yang dapat digunakan pada pasien gagal ginjal terminal salah satunya adalah hemodialisis. Hemodialisis merupakan suatu mesin pengganti ginjal buatan yang terdiri dari membran semipermeabel untuk membuang sampah metabolik atau toksin dari tubuh kemudian dibawa keluar oleh cairan dialisis (Ignatavicius \& Workman, 2013; Kallenbach et al., 2005). Hemodialisis ini digunakan oleh pasien GGT jangka panjang untuk memanajemen uremia, kelebihan cairan, dan ketidakseimbangan elektrolit (Price \& Wilson, 2006).

Hemodialisis merupakan terapi yang aman dan bermanfaat untuk pasien namun juga sebagai terapi yang rumit, tidak nyaman untuk pasien dan disertai dengan beberapa komplikasi. Beberapa komplikasi hemodialisis terdiri dari dua jenis yaitu komplikasi akut dan kronik (Mandal, 2014). Komplikasi pada pasien yang menjalani terapi hemodialisis dapat terjadi akut akibat langsung dari terapi hemodialisis yang sedang dijalani dan akibat jangka panjang karena hemodialysis kronis. Komplikasi ini sering kali muncul dan mengganggu pasien yang menjalani hemodialisis sehingga menyebabkan kehidupan pasien terganggu bahkan menyebabkan penurunan kualitas hidup pasien.

Hemodialisis menjadi terapi pengganti ginjal yang efektif dan paling banyak digunakan dalam penatalaksanaan gagal ginjal terminal. Hemodialisis merupakan terapi yang aman dan bermanfaat untuk pasien namun sekaligus menjadi terapi yang rumit dan tidak nyaman yang disertai dengan beberapa komplikasi. Hemodialisis tidak mampu menyembuhkan, memulihkan ataupun mengganti aktivitas metabolik atau endokrin yang dilakukan ginjal sehingga pasien gagal ginjal terminal yang menjalani hemodialisis akan tetap mengalami gangguan baik dari penyakitnya ataupun efek samping dari terapi hemodialisis.

Berdasarkan hasil screening dan studi dalam berbagai penelitian didapatkan pasien yang menjalani hemodialisis mengeluh adanya komplikasi yang ditimbulkan oleh terapi hemodialisis. Komplikasi yang sering dikeluhkan oleh pasien antara lain adalah kelelahan (fatigue), mual dan muntah, gatal-gatal (pruritus) dan nyeri saat kanulasi serta mengalami gangguan tidur. Komplikasi-komplikasi ini kerap kali muncul sehingga menyebabkan pasien terganggu. Kegiatan ini bertujuan untuk memberikan pengetahuan dan informasi terkait pengelolaan manajemen komplikasi/ keluhan hemodialisis sehingga pasien mempunyai keterampilan yang dapat digunakan untuk menurunkan/mengatasi komplikasi/keluhan yang dialami.

\section{METODE}

Kegiatan edukasi dilakukan di unit hemodialisis RSUP. Dr. M. Djamil Padang. Edukasi kesehatan dilakukan terhadap 32 orang pasien. Edukasi diberikan melalui pemutaran video saat hemodialisis berlangsung. Adapun metode pelaksanaan kegiatan edukasi kesehatan ini adalah sebagai berikut:

1. Koordinasi kegiatan dengan perawat di unit hemodialisis RSUP. Dr. M. Djamil Padang terkait dengan prosedur teknis yang akan dilakukan pada kegiatan edukasi kesehatan ini.

2. Menyiapkan media yang akan digunakan pada kegiatan edukasi. Media yang akan digunakan pada kegiatan edukasi kesehatan ini adalah video dan modul mengenai komplikasi/keluhan 
hemodialisis dan manajemen komplikasi/keluhan hemodialisis.

3. Penyuluh melakukan skrining kepada pasien hemodialisis mengenai komplikasi/keluhan yang dialami oleh pasien. Hal ini bertujuan untuk mengetahui pengetahuan pasien tentang komplikasi/keluhan yang disebabkan oleh hemodialisis. Selanjutnya, skrining ini juga bertujuan untuk mengetahui penanganan yang selama ini dilakukan oleh pasien untuk mengatasi/ mengurangi komplikasi/keluhan hemodialisis yang dilakukan oleh pasien.

4. Penyuluh melakukan edukasi kesehatan kepada pasien yang menjalani hemodialisis. Sesi edukasi kesehatan diberikan pada saat pasien menjalani hemodialisis melalui pemutaran video yang berdurasi \pm 20 menit. Setelah pemutaran video selesai, penyuluh kemudian memberikan modul yang berisi informasi mengenai komplikasi/keluhan hemodialisis dan manajemen komplikasi/keluhan hemodialisis. Diharapkan dengan pemberian modul ini pasien dapat mengingat kembali materi penanganan komplikasi/keluhan hemodialisis yang telah disampaikan saat edukasi berlangsung.

5. Penyuluh mengevaluasi pemahaman pasien setelah pemberian materi edukasi.

\section{HASIL DAN PEMBAHASAN}

Kegiatan edukasi dilaksanakan di Unit Hemodialisis RSUP. Dr. M. Djamil Padang yang dilakukan tanggal 26-27 Oktober 2020. Tim dosen yang melakukan edukasi adalah Ns. Devia Putri Lenggogeni, M.Kep, Sp.Kep.MB, Hema Malini S.Kp, MN, Ph.D, Ns. Bobby Febri Krisdianto, M.Kep, dan dibantu oleh dua orang mahasiswa serta perawat yang berdinas di ruangan hemodialisis. Edukasi yang dilakukan adalah pemberian informasi dan pengetahuan untuk meningkatkan keterampilan pasien dalam menangani komplikasi/keluhan yang dirasakan. Edukasi diberikan selama pasien menjalani hemodialisis dengan melakukan pemutaran video dan pemberian booklet kepada pasien. Adapun karakteristik pasien yang mengikuti kegiatan ini dapat dilihat pada Tabel 1.

Tabel 1. Karakteristik Pasien yang Mengikuti Kegiatan Manajemen Komplikasi/ Keluhan Hemodialisis

\begin{tabular}{lcc}
\hline & Frekuensi & \% \\
\hline Usia & 11 & 34.3 \\
Usia awal $(17-44$ tahun $)$ & 13 & 40.7 \\
Usia pertengahan $(45-59$ tahun) & 8 & 25 \\
Usia lanjut $(60-70$ tahun) & & \\
Jenis Kelamin & 18 & 56.3 \\
Laki-laki & 14 & 43.7 \\
Perempuan & & \\
\hline Lama Hemodialisis & 4 & 12.5 \\
$<1$ tahun & 10 & 31.3 \\
$1-3$ tahun & 10 & 31.3 \\
$>3-5$ ahun & 8 & 25 \\
$>5$ tahun & & \\
\hline Jadwal Hemodialisis & 22 & 68.8 \\
Pagi & 10 & 31.2 \\
Sore & 32 & 100 \\
\hline Total & & \\
\hline
\end{tabular}


Berdasarkan data di Tabel 1, diketahui pasien yang mengikuti kegiatan edukasi manajemen komplikasi/keluhan ini adalah usia pertengahan (45-59 tahun) sebanyak 13 orang (40.7\%), berjenis kelamin laki-laki sebanyak 18 orang (56,3\%), lama menjalani hemodialisis 1-3 tahun sebanyak 10 orang (31.3\%), >3 -5 tahun sebanyak 10 orang $(31,3 \%)$ dan dengan jadwal hemodialisis pada pagi hari sebanyak 22 orang (68.8\%).

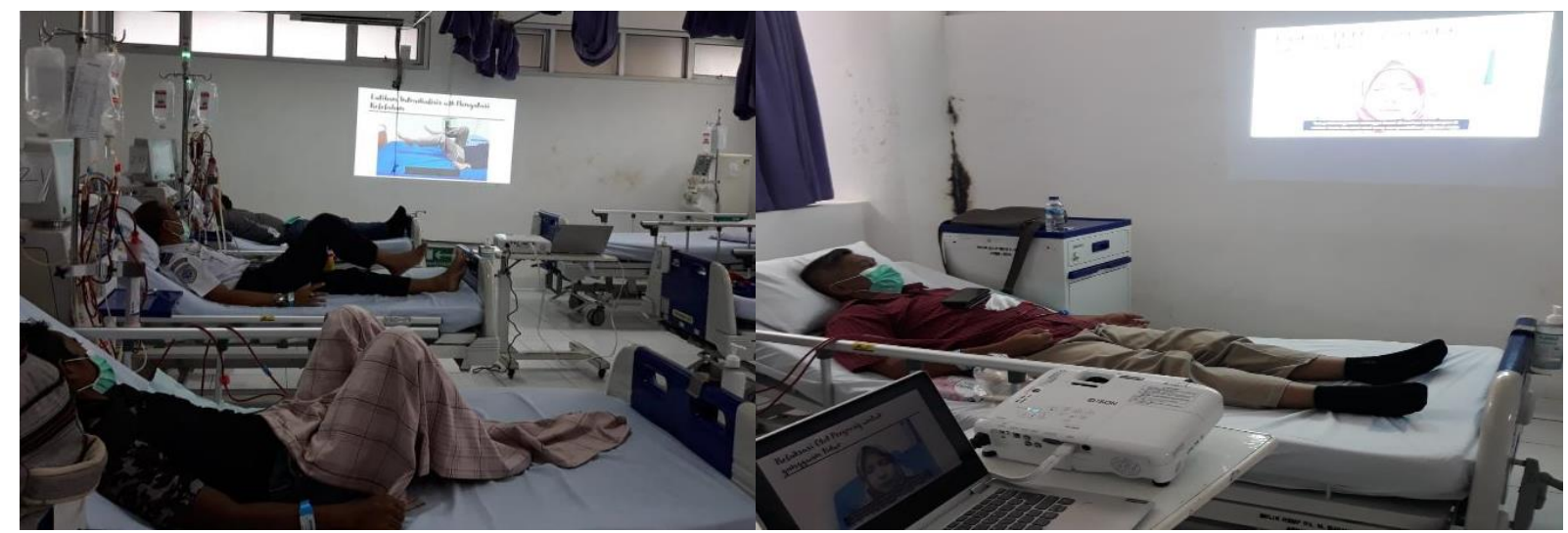

Gambar 1. Kegiatan Edukasi Manajemen Komplikasi/Keluhan Hemodialisis

Selanjutnya, Tabel 2 akan menjelaskan komplikasi/keluhan yang dialami oleh pasien yang menjalani hemodialisis. Berdasarkan Tabel 2, diketahui komplikasi atau keluhan yang banyak dialami oleh pasien yang mengikuti kegiatan pengabdian masyarakat ini adalah pruritus sebanyak 30 orang (93.8\%), kelelahan/fatigue sebanyak 28 orang (87.5\%).

Tabel 2. Komplikasi/Keluhan yang Dialami Pasien yang Menjalani Hemodialisis

\begin{tabular}{lcc}
\hline Komplikasi/ Keluhan Hemodialisis & Frekuensi & $\mathbf{\%}$ \\
\hline Kelelahan & 28 & 87.5 \\
Pruritus & 30 & 93.8 \\
Mual Muntah & 18 & 56.3 \\
Kram Otot & 26 & 86.7 \\
Nyeri Penusukan AV-Fistula & 26 & 86.7 \\
Gangguan Tidur & 26 & 86.7 \\
\hline
\end{tabular}

Tabel 3 memberikan informasi terkait dengan pengetahuan pasien dalam mengelola dan menangani komplikasi/keluhan hemodialisis. Berdasarkan Tabel 3, diketahui masih rendahnya pengetahuan pasien terhadap manajemen komplikasi/keluhan hemodialisis. Pengetahuan pasien terhadap pengelolaan komplikasi/keluhan sebelum edukasi paling tinggi adalah pada pengelolaan kram otot, dimana dari 26 orang pasien, 20 orang pasien $(76.7 \%)$ mengetahui pengelolaan kram otot yang terjadi selama hemodialisis. Dari hasil wawancara, diketahui hampir sebagian besar pasien menjawab pengelolaan otot yakni dengan melakukan pemijatan pada daerah yang mengalami kram otot. Namun, pasien tidak mengetahui cara menghindari atau meredakan nyeri kram otot selama hemodialisis melalui latihan intradialis dan mengontrol penambahan berat badan intradialisis. Kegiatan ini memberikan informasi mengenai latihan intradialisis dan mengontrol penambahan intradialisis sebagai manajamen untuk mengurangi kejadian kram otot pada pasien yang menjalani hemodialisis. Setelah diberikan informasi terkait manajemen komplikasi/keluhan hemodialisis didapatkan hasil 32 orang $(100 \%)$ mengetahui latihan intradialisis dan pengontrolan berat badan interdialisis bermanfaat untuk mengurangi dan mengontrol kejadian kram otot pada pasien yang menjalani hemodialisis. 
Tabel 3. Gambaran Pengetahuan Terkait dengan Manajemen Komplikasi/Keluhan Hemodialisis Sebelum dan Sesudah Edukasi

\begin{tabular}{lcccc}
\hline Komplikasi/Keluhan & \multicolumn{2}{c}{ Pre } & \multicolumn{2}{c}{ Post } \\
\cline { 2 - 5 } & Frekuensi & \% & Frekuensi & $\%$ \\
\hline Kelelahan & 12 & 42.9 & 28 & 100 \\
a. Tahu & 16 & 57.1 & 0 & 0 \\
b. Tidak & & & & \\
\hline Pruritus & 18 & 60 & 30 & 100 \\
a. Tahu & 12 & 40 & 0 & 0 \\
b. Tidak & & & & \\
\hline Mual Muntah & 6 & 33.3 & 18 & 100 \\
a. Tahu & 12 & 66.7 & 0 & 0 \\
b. Tidak & & & & \\
\hline Kram otot & 20 & 76.7 & 26 & 100 \\
a. Tahu & 6 & 23.3 & 0 & 0 \\
b. Tidak & & & & \\
\hline Nyeri Penusukan AV-Fistula & 4 & 14.4 & 26 & 100 \\
a. Tahu & 22 & 85.6 & 0 & 0 \\
b. Tidak & 6 & 23.3 & 26 & 100 \\
\hline Gangguan Tidur & 20 & 76.7 & 0 & 0 \\
a. Tahu & & &
\end{tabular}

Keluhan pruritus merupakan keluhan hemodialisis yang banyak dialami oleh pasien yang menjalani hemodialisis. Dari kegiatan ini sebagian besar pasien yang mengikuti kegiatan mengeluh adanya pruritus yakni sebanyak 30 orang (93.8\%). Sebanyak 18 orang sudah mengetahui manajemen untuk menangani pruritus. Manajemen farmakologi dan nonfarmakologi untuk menangani atau mengurangi gejala pruritus. Melalui kegiatan ini diketahui bahwasanya pasien mengelola pruritus melalui mengkonsumsi obat-obatan dan penggunaan terapi topikal. Kegiatan ini memberikan informasi dan pengetahuan kepada pasien mengenai penggunaan terapi topikal untuk mengurangi gejala pruritus yang dirasakan oleh pasien. Terapi topikal yang dapat digunakan antara lain penggunaan virgin coconut oil (VCO) atau baby oil. Penggunaan VCO atau baby oil terbukti efektif untuk mengurangi gatal karena mampu menghambat transmisi gatal yang bearasal dari serabut saraf $\mathrm{C}$ dan dapat meminimalkan peradangan dan stimulasi kimia. Selain itu, aplikasi baby oil juga dapat meringankan gejala xerosis dan deskuamasi (Lin et al., 2011). Setelah diberikan informasi terkait manajemen komplikasi/ keluhan hemodialisis didapatkan hasil 32 orang (100\%) mengetahui penggunaan terapi topikal yakni VCO dan baby oil merupakan salah satu alternatif untuk mengurangi gejala pruritus.

Keluhan fatigue atau kelelahan post hemodialisis merupakan salah satu keluhan yang paling banyak dialami oleh pasien yang menjalani hemodialisis. Diketahui 28 dari 32 orang (87.5\%) pasien yang mengikuti kegiatan ini mengeluh mengalami fatigue/kelelahan. Namun hanya 12 orang (42.9\%) yang mengetahui penanganan keluhan fatigue/kelelahan ini. Akan tetapi pengelolaan yang dilakukan pasien inipun masih belum tepat. Banyak pasien mengelola fatigue mereka dengan hanya berisitirahat saja. Berbagai penelitian telah menyarankan bahwa latihan intradialisis efektif dalam mengurangi keparahan fatigue (Maniam et al., 2014). Latihan intradialisis merupakan latihan yang dilakukan selama hemodialisis yang terdiri dari gerakan aktif dan pasif pada ekstremitas atas dan bawah (Mahrova \& Svagrova, 2013). 
Penggunaan range of motion (ROM) merupakan latihan intradialisis banyak direkomendasikan untuk mengurangi fatigue/kelelahan setelah hemodialisis. Pada kegiatan ini, pasien diberikan informasi bahwasanya latihan intradialisis berupa range of motion dapat menjadi salah satu alternatif untuk mengurangi fatigue/kelelahan setelah menjalani hemodialisis. Kegiatan ini menayangkan video latihan intradialsis yang dapat memberikan manfaat untuk mengurangi fatigue/kelelahan yang dialami oleh pasien. Setelah diberikan informasi terkait manajemen komplikasi/keluhan hemodialisis didapatkan hasil 32 orang (100\%) mengetahui latihan intradialisis berupa ROM bermanfaat untuk mengurangi atau mengatasi fatigue yang disebabkan oleh hemodialisis.

Keluhan berikutnya yang banyak dialami oleh pasien yang menjalani hemodialisis adalah nyeri penusukan AV-fistula. Sebanyak 26 dari 32 orang (86.7\%) mengeluhkan keluhan nyeri akibat penusukan AV-fistula. Nyeri yang dirasakan pasien saat penusukan akan berbeda pada setiap pasien tergantung kepada ambang batas nyeri masing-masing individu. Sebanyak 22 orang $(85.6 \%)$ tidak mengetahui pengelolaan nyeri penususkan AV-fistula. Hanya 4 orang $(14.4 \%)$ yang mengetahui pengelolaan nyeri penusukan AV-fistula yakni dengan mengoleskan obat. Pada kegiatan ini pasien yang menjalani hemodialisis diberikan pengetahuan dan informasi terkait pengelolaan untuk mengurangi penusukan AV-fistula melalui pemijatan titik Li-4 dan juga cryotherapy. Tindakan ini merupakan tindakan non-farmakologi mandiri yang dapat dilakukan oleh pasien.

Penurunan nyeri melalui tindakan ini pemijatan dapat dijelaskan karena pemijatan pada titik LI-4 menghambat rangsangan nyeri sampai ke system saraf pusat sehingga cidera atau kerusakan yang terjadi tidak dipersepsikan otak sebagai nyeri (Mirtajadini, Kalroozi, \& Pishgooie, 2016). Selanjutnya, penuruan rangsangan nyeri melalui tindakan cryotherapy dapat dijelaskan untuk menstimulasi serabut-serabut syaraf dengan mentramisikan sensasi tidak nyeri dengan memblok atau menghambat transmisi impuls nyeri. Setelah diberikan informasi terkait manajemen komplikasi/ keluhan hemodialisis didapatkan hasil 32 orang (100\%) mengetahui pemijatan Li-4 dan tindakan cryotherapy dapat menurunkan nyeri penusukan AV-fistula.

Keluhan gangguan tidur dialami oleh 26 dari 32 orang (86.7\%). Gangguan tidur merupakan salah satu gangguan yang sering dilaporkan secara subjektif oleh pasien yang menjalani hemodialisis (Black \& Hawks, 2009; Parker et al., 2003). Dari kegiatan pengabdian masyarakat ini diketahui hanya 6 orang (23.3\%) yang mengetahui manajemen gangguan tidur. Manajemen gangguan tidur yang dilakukan adalah dengan mengkonsumsi obat tidur. Pada kegiatan ini pasien diberikan informasi terkait manajemen gangguan tidur salah satunya dengan relaksasi otot progresif. Kegiatan pemberian dan informasi ini menunjukkan 32 orang (100\%) yang mengikuti kegiatan ini mengetahui tindakan relakasai otot progresif merupakan tindakan alternatif yang dapat dilakukan untuk mentasi keluahan gangguan tidur.

Keluhan yang juga banyak dirasakan pada pasien menjalani hemodialisis adalah mual dan muntah. Sebanyak 18 orang (56.3\%) dari 32 orang yang mengikuti kegiatan ini mengeluh adanya mual dan muntah. Mual dan muntah pada pasien hemodialysis cukup mengganggu status nutrisi pasien (Chong \& Tan, 2013). Dimana 12 orang (66.7\%) yang mengikuti kegiatan ini tidak mengetahui pengelolaan mual muntah. Banyak teknik non farmakologis yang dapat dilakukan untuk mengurangi gejala mual muntah pada pasien hemodialysis mulai dengan pengaturan makan, oral hygiene, kompres dingin hingga intervensi relaksasi seperti akupressure. Salah satu hal yang dapat dilakukan untuk mengatasi rasa mual dan muntah yang dialami oleh pasien HD yaitu dengan melakukan akupresur pada titik P-6. Penelitian yang dilakukan oleh Asgari et al. (2020) menunjukkan akupresur yang dilakukan pada titik P-6 dapat mengurangi keluhan mual selama menjalani hemodialisis. Kegiatan ini memberikan informasi dan pengetahuan mengenai berbagai teknik untuk mengurangi mual dan muntah dengan pengaturan makan dan pemijatan titik P-6. Dari hasil kegiatan ini, setelah diberikan informasi terkait manajemen komplikasi/ 
keluhan hemodialisis diketahui 32 orang (100\%) pasien yang mengikuti kegiatan ini mengetahui pengaturan makan dan pemijatan Li-6 menjadi alternatif untuk mengurangi mual dan muntah pada pasien yang menjalani hemodialisis.

Kegiatan pengabdian masyarakat ini berkaitan dengan salah satu tugas perawat sebagai edukator dan advokator. Sebagai seorang edukator, perawat mempunyai tanggung jawab untuk memberikan transfer ilmu kepada pasien. Kegiatan pengabdian ini memberikan pengetahuan kepada pasien yang menjalani hemodialisis terkait dengan manajemen komplikasi dan keluhan yang disebabkan oleh penyakit ginjal kronik ataupun hemodialisis. Selanjutnya, kegiatan ini juga merefleksikan tugas perawat sebagai advokator yang mempunyai tanggung dalam memberikan pelayanan yang tidak merugikan dan memberikan manfaat nyata. Oleh karena itu pemberian pendidikan kesehatan menjadi salah satu peran dan tanggung jawab yang penting untuk dilaksanakan.

Pendidikan kesehatan melalui kegiatan edukasi merupakan proses kegiatan belajar setiap individu bertujuan untuk meningkatkan kualitas dari pola pikir, pengetahuan serta mengembangkan potensi dari masing-masing individu. Kegiatan ini memberikan edukasi terkait manajemen hemodialisis/keluhan pasien yang menjalani hemodialisis. Kegiatan ini bertujuan untuk memberikan pengetahuan dan informasi terkait pengelolaan manajemen komplikasi/ keluhan hemodialisis sehingga pasien mempunyai keterampilan yang dapat digunakan untuk menurunkan/mengatasi komplikasi/keluhan yang dialami.

Manajemen komplikasi dan keluhan hemodialisis diberikan kepada pasien yang menjalani hemodialisis sebagai bentuk perawatan komprehensif kepada pasien. Kegiatan ini diharapkan dapat meningkatkan pengetahuan pasien terhadap intervensi untuk mengurangi gejala komplikasi. Selanjutnya, diharapkan pasien melakukan perawatan secara mandiri untuk mengurangi gejala yang diakibatkan oleh penyakit ginjal dan hemodialisis.

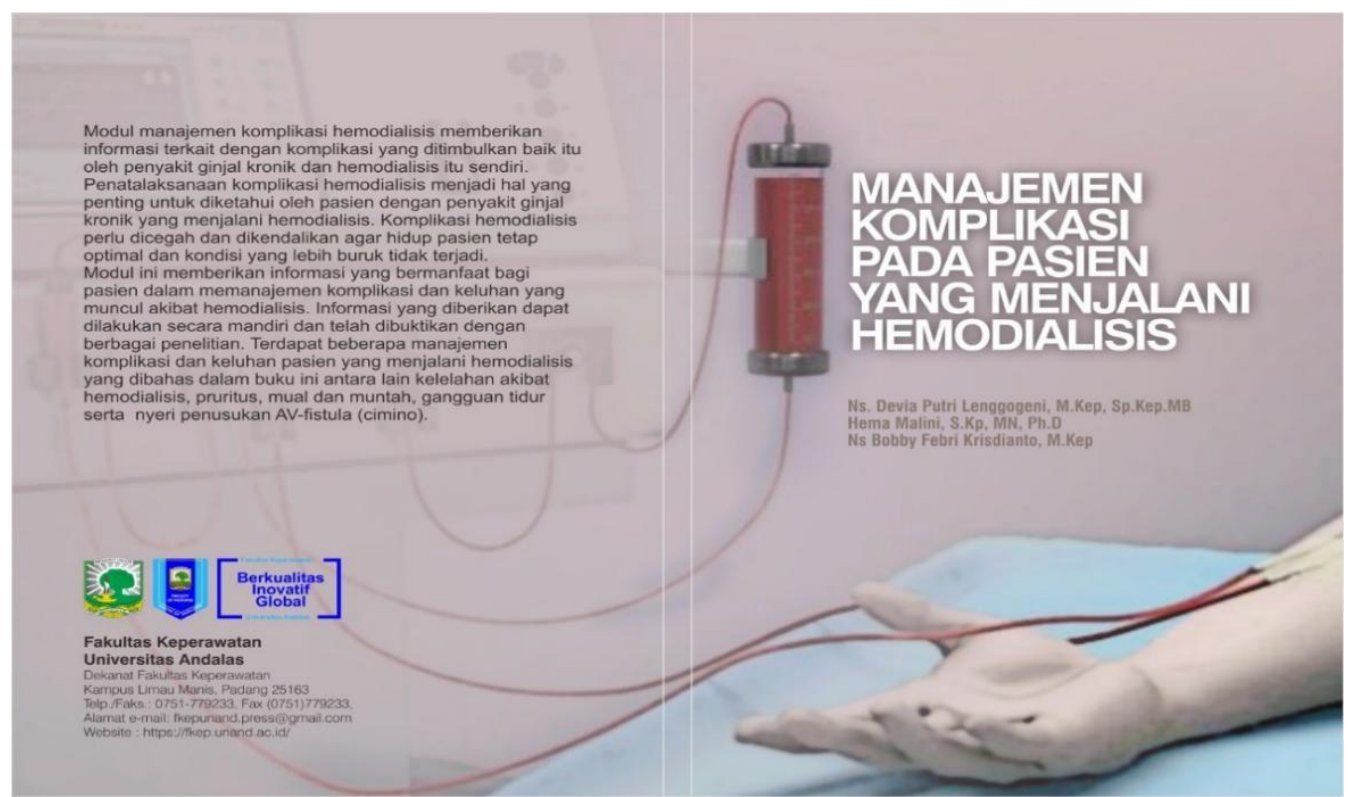

Gambar 2. Modul Edukasi yang Dibagikan untuk Pasien 


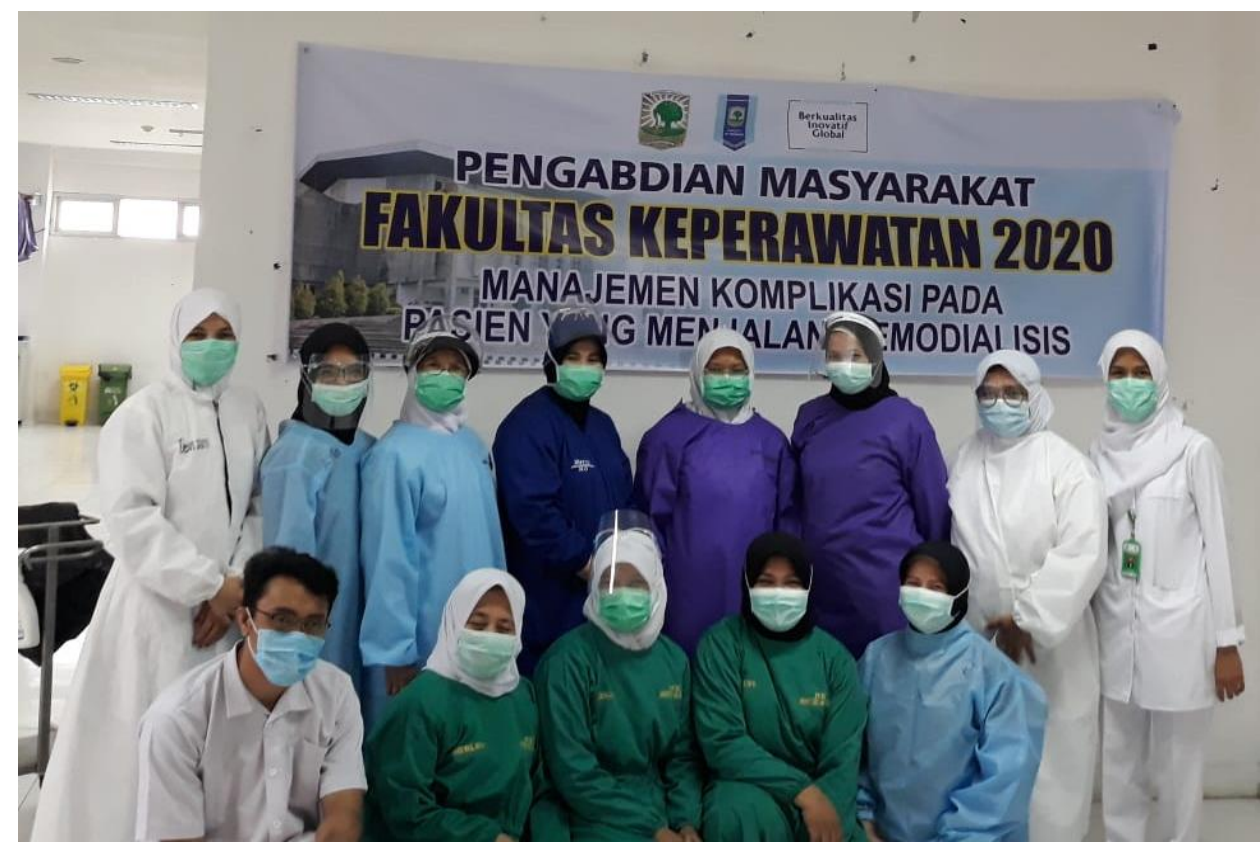

Gambar 3. Tim yang Terlibat pada Kegiatan Edukasi Manajemen Komplikasi/Keluhan Hemodialisis

\section{KESIMPULAN}

Manajemen komplikasi/ keluhan yang diberikan pada kegiatan ini bertujuan untuk meningkatkan pengetahuan dan keterampilan pasien dalam mengelola komplikasi/keluhan yang dirasakan. Terlihat dari kegiatan ini pengetahuan pasien meningkat setelah kegiatan edukasi. Meskipun peningkatan keterampilan tidak dapat secara langsung terlihat dalam kegiatan ini, namun dengan peningkatan pengetahuan yang didapatkan oleh pasien diharapkan pada akhirnya meningkatkan keterampilan pasien dalam penanganan komplikasi hemodialisis.

\section{UCAPAN TERIMA KASIH}

Terima kasih kepada UP2M Fakultas Keperawatan Universitas Andalas sebagai penyandang dana sehingga kegiatan ini terlaksana dengan baik. Selanjutnya kepada unit hemodialisis RSUP. Dr. M. Djamil yang telah memberikan izin dan sejawat yang telah berpartisipasi dalam penyelenggaraan kegiatan ini serta peserta yang telah ikut dan berkontribusi dalam penyelenggaraan kegiatan ini.

\section{DAFTAR PUSTAKA}

Asgari, M. R., Asghari, F., Ghods, A. A., Ghorbani, R., \& Motlagh, N. H. (2020). The effect of acupressure on the severity of nausea during hemodialysis. Crescent Journal of Medical and Biological Sciences, 7(1), https://www.cochranelibrary.com/central/doi/10.1002/central/CN-02074492/full Black, J. ., \& Hawks, J. . (2009). Medical Surgical Nursing: Clinical Management for Positive Outcomes (8th ed). Elsevier. 
Chong, V. H., \& Tan, J. (2013). Prevalence of gastrointestinal and psychosomatic symptoms among Asian patients undergoing regular hemodialysis. Nephrology, 18(2), 97-103. https://doi.org/10.1111/nep.12000

Ignatavicius, D. ., \& Workman, M. . (2013). Medical Surgical Nursing Patient Center Collaborative Care (7th editio). Elsevier.

Kallenbach, J. ., Gutch, C. ., Martha, S. ., \& Corca, A. . (2005). Review of Hemodialysis for Nurse and Dialysis Personel. Elsevier.

Lin, T., Lai, Y., Guo, S., Liu, C., Tsai, J., \& Guo, H. (2011). Baby oil therapy for uremic pruritus in haemodialysis patients. Journal of Clinical Nursing, 21, 139-148. https://doi.org/10.1111/j.1365-2702.2011.03906.x

Mahrova, A., \& Svagrova, K. (2013). Exercise Therapy-Additional Tool for Managing Physical and Psychological Problems on Hemodialysis (pp. 753-821).

Mandal, A. . (2014). Text Book of Nephrology (3rd ed.). Jaypee Brothers.

Maniam, R., Subramanian, P., Kaur, S., \& Singh, S. (2014). Preliminary study of an exercise programme for reducing fatigue and improving sleep among long-term haemodialysis patients. Singapore Med J, 55(9), 476-482. https://doi.org/10.11622/smedj.2014119

Mirtajadini, H., Kalroozi, F., Pishgooie, A.H. (2016). Shiatsu massage and the pain intensity of venipuncture in patients undergoing hemodialysis. Military Caring Science, 3(1), 27-33.

Parker, K. P., Bliwise, D. L., Bailey, J. L., \& Rye, D. B. (2003). Daytime sleepiness in stable hemodialysis patients. American Journal of Kidney Diseases, 41(2), 394-402. https://doi.org/10.1053/ajkd.2003.50049

Price, Wilson. 2006. Patofisiologi Vol 2 ; Konsep Klinis Proses-proses Penyakit. Penerbit Buku Kedokteran. EGC. Jakarta.

Sukandar, E. (2013). Nefrologi Klinik. Pusat Informasi Ilmiah (PII) Departemen Ilmu Penyakit Dalam Fakultas Kedokteran Universitas Indonesia.

Suwitra, K. (2014). Penyakit Ginjal Kronik. In Buku Ajar Penyakit Dalam (Edisi 6, pp. 2156-2165). Interna Pusblishing. 